\title{
Content Analysis and Understanding of the First Local History of Sheki Province in the $19^{\text {th }}$ Century
}

\author{
Sajjad Hosseini ${ }^{1} \&$ Hossein Mir J'afari ${ }^{1} \&$ Loghman Dehghan Niyeri ${ }^{1}$ \\ ${ }^{1}$ History Department, University of Isfahan, Isfahan, Iran \\ Correspondence: Sajjad Hosseini, History Department, University of Isfahan, Hezar Jarib Street, Isfahan, Iran. Tel: \\ 98-914-419-7328. E-mail: sajjad_hoseani@yahoo.com
}

Received: January 24, 2013 Accepted: April 4, 2013 Online Published: April 17, 2013

doi:10.5539/res.v5n2p135 URL: http://dx.doi.org/10.5539/res.v5n2p135

\begin{abstract}
Sheki is one of the most important Moslem provinces of the Southern Caucasia. A series of local histories have emerged in this region the first of which is A Brief History of the Sheki Khans by Karim Agha Fateh. For years, this work had existed in manuscript form and when it was introduced to the world of historiography science, inadequate and erroneous information were produced about it.

Using analytic-descriptive method and relying on library sources, this study attempts to fully introduce this work as well as to analyze its content and writing style.
\end{abstract}

Keywords: local historiography, $19^{\text {th }}$ century (C.E), content analysis, Sheki, Karim Agha Fateh

\section{Introduction}

Sheki or Nukha is one of the most important provinces of the Southern Caucasia. Like other provinces in this region, Sheki sought independence after the murder of Nader Shah (1747) and disobeyed the central government (Ismayil, 1997, p. 12). However, Persian ruling governments always considered the entire Southern Caucasian region including Sheki as part of their territory. In the process of the Russian advance toward Southern Caucasian regions, two series of wars broke out between Persia and Russia. Following the cessation of the first series of wars, the Treaty of Gulistan (1813) was signed according to which Sheki, like many other Southern Caucasian cities, was annexed to Russia (Qodsi, 1382, p. 251). Previously, Salim Khan of the Sheki khans had declared allegiance to the Russian government according to the Kurakchay Treaty (1805) (Garabaghi, 1384, p. 124; Adigozel Bey, 2006, p. 82). During the period the Russia government dominated the region, the tradition of local historiography thrived in Sheki as it did in other Moslem Southern Caucasian provinces. The first local history of Sheki appeared in a work called A Brief History of the Sheki Khans by Karim Agha Fateh in nineteenth century.

This study attempts to carry out a content analysis on this book through library research. Different parts of this research include:

1. Identification of author

2. Description and analysis of the content

3. Writing style which answer the following questions:

- Who is the author of A Brief History of the Sheki Khans? and what is the reason for the error some scholars make in this matter?

- In what respects is A Brief History of the Sheki Khans influenced by Persian Historiography tradition?

and 3. was writing of $A$ Brief History of the Sheki Khans, like many other local histories of the region, sponsored by the Tsarian Russia?

\section{Identification of the Author}

A Brief History of the Sheki Khans was made known to the scientific world in 1858 . B. Dorn published this work in a collection of historical works titled Al-entekhabat-ul Bahyiah in Petersburg. This books was translated 66 years into Azerbaijani Turkish along with its Russian translation by the Azerbaijan Research and Analysis Association. Unfortunately, however, a serious blunder was committed in both publications and the writing of 
the book was ascribed to a person who was not the actual author. In his introduction to Al-entekhabat-ul Bahyiah, Dorn writes, 'in 1858, Khankov thus wrote about the author of $\mathrm{t}$ this work: "the author of The Brief History of Sheki cannot be anybody but Hadji Abdul Latif Afandi who was my friend and one of the Sheki judges and son of Hadji Abdul Salim Afandi. He is now sixty years old. He knows Arabic very well. He is also well acquainted with Persian literature and poetry. From 1845 to 1846, he travelled to Istanbul, Egypt and Mecca and returned to his homeland by the route of Syria, Baghdad, Karbala, Hamadan, Tehran, Tabriz and Shusha. He visited Dagestan in 1848 and has lived a comfortable life with his family in Nuxa. This good-looking old man spoke Persian and Turkish very fluently. I have been his guest two times in 1848 and 1849" (Babayev, 1993, p. 3; Soviet Azerbaijan Encyclopedia, 1981, p. 353).

It is clear from this that the reason for Dorn's mistake has been the unquestionable and reliable knowledge of the famous Caucasologist, N. Khankov. It appears that the mistake was caused by Dorn and Khankov not having scrutinized the transcript. Other scholars including Ashmarin and Dadashov have neglectfully let themselves be misled by the mistake of the two mentioned orientalists.

This mistake was first discovered by Salman Mumtaz, one of Sheki's specialists in the fields of poetry, literature and manuscripts (Pashayeva, 2005, p. 3; People's Republic of Azerbaijan Encyclopedia, 2005, p. 328).

In an article titled "Criticism and Remarks" published in issues 2 and 3 of the journal Ma'aref-e Ishchisi in 1929, Mumtaz points out this issue. In this article, he cogently argues that the author of this small yet invaluable book is a descendant of Hadji Chalabi, son of Fath Ali Khan, the last Sheki Khan, Karim Agha known as Fateh. Here is the conclusion to Mumtaz's research about the genealogy of the author: "Fath Ali Khan is the great grandson of the famous Hadji Chalabi, grandson of Hassan Agha and son of Muhammad Hussein Khan known as Moshtaq Fath Ali Khan had a son who is the very well-known, Persian and Turkish poet, Karim Agha Fateh (Babayev, 1993, p. 4; Aliyarli, 2007, p. 247).

Distinguished Turkish scholar and Mumtaz's contemporary, Zaki Valadi Toghan mentions Karim Agha as the author of A Brief History in his lectures from 1928 through 1931 in Istanbul University and writes, "one of the last representatives of this generation (Sheki Khans) is Karim Agha, son of Fath Ali Khan, who lived in the beginning of the $19^{\text {th }}$ century. He has penned a book about the history of Sheki which has been attributed to the Sheki judge, Abdul Latif Afandi (Veledi, 2009, p. 51).

The fact is that contrary to the existing tradition of the Orient's written literature, the author has decided not to insert his name at the beginning and the end of the book. However, as pointed out by Mumtaz, he makes implicit references to the authorship of the book throughout the text. In one part of the book, Karim Agha expresses his relation with Sheki khans and Muhammad Hassan Khan and Fath Ali Khan in this manner: "My father, Fath Ali Khan, is Muhammad Hassan Khan's brother" (Fateh, 1384, p. 146).

In some other part of the book, he refers to Fath Ali Khan as his father and writes about his promotion to the station of a Sheki khan in this way: "the Sheki people, young and old, have gathered around my father, Fath Ali Khan, have taken pledges and have concluded to appoint him khan in 1219 AH" (Fateh, 1384, p. 150).

Karim Agha, son of Fath Ali Khan, was born in Sheki in 1783. His family with the Russian surname "Sheki Khanov", indicating their social class and origin, was a famous one. He was educated under his father's supervision and taught in Arabic and Persian. He had poetic gift and chose the pseudonym "Fateh" in poetry and soon became one of the celebrities of Sheki literature. He was friends with Mirza Fath Ali Khan Akhundzadeh and always kept his memory alive by sending him precious gifts. Fateh passed away in Sheki in 1858 (Kocherli, 1925, p. 528; Ziyad Khan, 1389, p. 82).

He has a collection of poetry mainly in Persian with some poems in Azerbaijani Turkish. Fereydun Kocherli has found only two of such poems to include in his literary anthology and says, "It is regretful Fateh has not produced other works in Turkish" (Kocherli, 1925, pp. 528, 530).

\section{Description and Analysis of the Content}

\subsection{Title of the Work}

The original title of this book according to the version published in Baku is A Brief History of Sheki Khans whereas it is titled The History of Sheki Khans in its Persian translation by Hussein Ahmadi. The translator himself is unhappy about using the term Khans in the title of the book and considers this term a historical distortion by the Tsarian Russian government to dilute the fact that Iran has sovereignty over this area (Ahmadi, 1384, p. 23). 


\subsection{Language of the Work}

This works is writer in Azerbaijani Turkish. The author's style is devoid of any literary pedantry and laboriousness and the work is written in a simple style. Unlike many other historiographical works of the old world, A Brief History of the Sheki Khans lacks any prologue or epilogue replete with literary figures.

Creating historiographical works in Azerbaijani Turkish has not been in popular in the period and region discussed here and most historiographical works were written in Persian. Furthermore, as said before, Fateh was more used to writing in Persian that Turkish. The text's over-simplicity and its proximity to the vernacular might have been affected by these conditions. Therefore, for reasons unknown to us, the author, in a break with literary traditions, creates a historiographical work not in Persian, but in Azerbaijani Turkish.

Years later, when writing the Russian-commissioned book Garabagh History, Mir Mehdi Khezani expressed the arduousness of this tradition breaking by saying "Turkish, is extremely simple and unornamented. For this reason, no writing worthy of offering to the knowledgeable can come out of this language and if words had been changed and integrated into structure and order or otherwise replaced with other expressions, it would not have been written in pure Turkish" (Khezani, 2006, p. 110).

\subsection{Structure and Content Description}

In this work, Karim Agha Fateh briefly addresses history of Sheki khans and leaders and observes political and military events related to rules of the dependent and independent rulers. The structural order of the work follows the chronological history of Sheki's leaders. The book can be divided into two story-like and historical sections. Several paragraphs from the book's opening pages include story-like narrations about Sheki khans and the historical section begins afterward. In terms of content, he historical section of the book can be divided into two subsections; the first subsection is based on information available in historiographical sources and the second subsection includes events contemporary with or close to the author's lifetime and the author, exploiting his ancestral origins, has collected these information.

The author begins his discussion of the Sheki history with mythical and ahistoric narrations and he himself, indeed, points to this fact: "it has been said that; but his actual existence has not been substantiated in historical books" (Fateh, 1384, p. 136). In these narrations, references have been made to a priest named Qara Keshish in Nuxa who had asked the hand of the daughter of Kish Village's priest for his son. However, since the priest's daughter was habituated to white water and the water in Nuxa was black, the father rejected the proposal and finally the affair ended happily by digging a channel from Kish to Nuxa and transferring white water. The name of Qara Kish's son was Jandar who converted to Islam and chose the Islamic name Ali Jan. Henceforth, the author refers to Ali Jan's son and grandson as Qutul Khan and Sheki (Fateh, 1384, p. 136).

Thereafter, Karim Agha's narratives become historiographical and the fate of Sheki khans contemporary with the Safavid government are cited based on a history book called Alam Ara. The story-like section of this local work is important in different respects. The narrative in this book to some extent brings to mind the well-known folkloric story of Asli and Karam. The story of Asli and Karam is one of the most famous folkloric stories of Azerbaijan. According to this story, Karam, a Moslem Khan's son or prince is the actual lover of Qara Keshish (Qara Melik), the Christian priest's daughter. Karam's proposal is answered with the Christian priest's prejudice and in order to prevent this marriage, the priest leaves the region with his daughter; chasing after them, Karam finds himself wandering in the desert and the mountains and thus begins the original love story of Karam (Maleki, 1389, pp. 9-23; Barazandeh, 1388, p. 24). At least, the presence of the marriage theme and the name and title of Qara Keshish are common to both stories.

In addition, the similarity between Qutul Khan's name and the Sheki Province draws our attention to the mythical narratives about the relationship between names of cities and old kings and rulers. Although the writer does not fully address this matter, by inserting the sentence "The name of Qutul Khan's name is identical with Sheki" (Fateh, 1384, p. 136), he shows that such thinking existed at the time.

In this part of the book, we are informed about the conversion of Sheki leaders in an unknown period before the Safavids came to power. In other words, until that time, some Sheki people were Christians and the trend of conversion from Christianity to Islam had been still going on. Such a trend must have begun after the Alban Renaissance era in the $13^{\text {th }}$ century (C.E) and reached the 16th century. In this period, Christian Albans of the region, led by Hassan Jalal, sought to restore their racial-religious identity and in so doing, the Ganzasar Monastery was built and was turned into a center of Alban caliphate. This era came to an end after Hassan Jalal's death and after that, Albans' racial and religious position gradually weakened (Ahmadov, 2006, pp. 56-47).

Then again, conversion of one of the Christian spiritual family's members to the religion of Islam is worthy of 
consideration. Such conversion could have been influenced by the ruling conditions of the time. Presence of dominantly Moslem population in the area and/or being subjected to a powerful Moslem government can direct someone like Jandar, who also was a megalomaniac, to a new religion. Furthermore, the flexible spirit of the Christian Albans might have influenced this tendency. Albans converted to Islam sooner than their Georgian and Armenian Christian neighbors and only a small number of them in the mountainous regions remained Christians for centuries. Right now, there are still many Alban churches extant in the Sheki region, particularly in the historical village of Kish.

The historical part of the book begins by reporting the conditions of Sheki khans who were contemporary with the Safavid rule. This section of the book is based on historiographical sources and the author refers to his using a source called "Alam Ara". In this part of the book, Hassan Sultan and Darvish Muhammad Khan's political and military activities in the Sheki province are mentioned.

Then, without referring to the sources he has used, the writer talks about the transition of power from the house of Darvish Muhammad Khan to the house of Hussein Jan; the khans of this ruling house are called Eski Meliklu In Sheki and all of them are titled and addressed as Melik (Fateh, 1384, p. 138).

In the meanwhile, a slight change occurs in the governmental system of the Sheki Province and that is the transformation from a khanate ruling system to Meliki. The Meliki system had come into existence since the Mongol era in the Southern Caucasia; some cases of this ruling system have been observed even in the Safavid era and later. The Meliks were, in fact, Moslem and Christian noblemen who had semi-independent governments under larger powers (Melikov, 2004, p. 270). The Safavid government had always had several Meliki provinces in its dominion. The Safavid government, because of the limited power and the dependency of most Meliks, preferred this type of semi-government to other ones. Whenever the Safavids felt danger about the increasing power of their rulers, they tried to limit them by installing a new dependent Melik.

Darvish Muhammad's desire for power and avoiding the central power which had begin since 945 A.H and continued to 958 A.H (Rumlu, 1357, pp. 373, 413, 433 \& 449; Monshi, pp. 135-136; Fateh, pp. 137-138) caused the Safavid government to establish the Melik rule of Eski Meliklu in Sheki in order to take the power from the local ruling house of Darvish Muhammad. Another case of such measure in the Southern Caucasian area took place years later against the local governors of Ganja and Shah Abbas of the Safavids, in order to limit their power, established the pentad Meliks in the Garabagh-e Kuhestan region. The pentad Meliks ruled in five regions of the Garabagh-e Kuhestan named Gulistan, Kharabret, Khachen, Varanda, and Dizek and practically lost their power when Panah Ali Khan-e Javanshir came to power and established the Garabagh Khanate in the middle of the $18^{\text {th }}$ century (Melik Hakupian, 1385, p. 15).

Further in the book, there are reports about the overthrowing of the Eski Meliklus and establishment of a new Melik led by Melik Hussein Qoli. It appears that in choosing new Meliks for this dominantly Sunnite province, the Safavids used Shiite Meliks; this is at least true about the last Melik of this Meliki dynasty, namely Melik Najaf. Perhaps, non-native Shiite Meliks have been more reliable for the Safavid government than native non-Shiite Meliks, particularly because local governors of these regions had formerly served the Shervanshahs and at first were by no means willing to obey the Safavid government.

Concerning the Sheki people's turning away from the Safavid government in 1500 (C.E), Ahsan-ul Tavarikh says, "In the meantime, the Sheki people began to defy the government. The Exaggerators burnt the blessing of their life with their unrelenting sword of praises" (Rumlu, 1357, p. 63).

Fateh talks about Melik Najaf's ill-considered policies regarding Sheki's Shiite and Sunnite peasants that brought about Sunnites' discontent. Finally, they complained to Nader Shah and he sent a man named Hadji Chalabi, a descendent of former Sheki khans, as a delegate to Melik Najaf. There are points in this part of the book that deserve consideration.

First of all, the historian lays special emphasis on the conflicts between the Shiite Melik and the dominantly Sunnite Sheki peasants (Qodsi, 1382, p. 22). These emphases on the part of the writer and his tone suggest his attachment to the Sunni faith.

Secondly, the historian refers to Shiites as "Qizilbashan" (Note 1) (Fateh, 1384, p. 139). The concept of qezelbash in different historical periods and geographies has always had various meanings and implications. In $19^{\text {th }}$ century, the Sunnite Moslems in Persia's neighboring lands used this word in its religious meaning "Shiite" (Shirvani, 1348, p. 385; Shirvani, 1337, p. 39; Asef, 2537, p. 122; Sami, 1314, p. 3659).

Thirdly, weather intentionally or not, the author mentions the dependency of local Sheki governors on Persian government. 
Finally, Hadji Chalapi was sent by Nader Shah to Malek Shah as a "delegate." It seems that local courts were small proxies for great Persian courts. As the occupation of delegation had been prevalent in the period studied here, a smaller form of this position presents itself in the local Sheki court. The position of delegation had changed throughout the Safavid, Afsharid and Zand period. However, this position was considered a prestigious one in all these periods and the delegate himself was the Shah's representative. The most famous and powerful delegate in this period was Karim Khan the Zand who never called himself "king" and became the representative of a prearranged Safavid King, Shah Ismail III (Savory, 1380, p. 218; Peery, 2008, p. 77).

The historical continues to talk about the predomination of Hadji Chalabi over Melik Najaf and his rebellion against Nader Shah. He regards this incident as a confrontation of Sunnites and Shiites. In fact, the measure Nader Shah took in giving power to Hadji Chalabi (appointing him delegate) has been an ill-considered action because Hadji Chalabi, because of his connection with the house of the old Sheki rulers and enjoying the public support of the Sunnites, had sufficient potential to demand independence and defy the central power (Fateh, 1384, p. 142).

Fateh talks about Hadji Chalabi's considerable power after Nader's death and the conspiracy of the region's khans to destroy him. The book continues with discussing the power struggles between Hadji Chalabi's sons and grandsons and how power continually went from hand to hand among brothers and nephews. These conflicts coincide with the coming to power of Muhammad Khan the Qajar and his interest in the Caucasian region and this time, each of the power-seeking Sheki khans attempts to overthrow his rivals by turning to the Persian king; indeed, their claim for independence trapped them into confrontation with Qajar armies. In the void created after the killing of Muhammad Khan the Qajar, the Sheki khans once more recommenced their rivalry (Fateh, 1384, p. 149).

The historian speaks about Salim Khan's, the last independent Sheki khan, allegiance to the Russian government. Of course, this obedience did not last long and with the massacre of Ibrahim Khan and his family by the Russians, Salim Khan, who had lost his sister (Ibrahim Khalil Khan's wife) in this episode, turns away from the Russians and to the Persian government. This time, with the Russian's domination in the Sheki province having had completed, another person from the ruling house of Hadji Chalabi, Fath Ali Khan, is chosen by the Russians as the Sheki khan. During the lifetime of the historian, the Russians take the rule in Sheki away from this family and transfer it to Ja' far Qoli Khan-e Khui (Fateh, 1384, pp. 150 \& 151).

\section{Writing Style}

\subsection{Reason for Writing}

The writer's relative connection with one of the most fundamental and oldest ruling house in Sheki makes one feel that he has set off to write this work in order to express the glories of his ancestors and eternalize his familial background in the form of history. Nevertheless, the beginning paragraph available in the version edited and translated by Hussein Ahmadi indicates the fact that Karim Agha Fateh, not unlike many other contemporary local writers, has been commissioned by one of the authorities to create his work. We know nothing about this authority figure, but with respect to the date of writing (1829), we may presume that Karim Agha, too, has been trying to respond to the Russians' historical obscurities. In this regard, he states, "You had asked me to inquire and search about the origin and genuineness of a series of khan and a series of events in Sheki province by asking the some of the informed and to write down the truth about this matter and submit it to your presence. I so did by asking some old people and inquired about the origin and genuineness of a series of khans and their children and a series of events and wrote them down according to the truth I found, as presented below, and I thus submit it to you" (Fateh, 1384, pp. 135-136).

Sponsoring creation of local historiographical works in the Moslem-populated Southern Caucasia has been one of the major policies of the Tsarian Russia. Other local works including History of Garabagh by Mirza Jamal Javanshir (Javanshir Garabaghi, 1384, p. 76), The Rule of Panah Khan and Ibrahim Khan in the Garabagh Province by Reza Qoli Bey Javanshir (Javanshir, 1384, p. 40), History of Ganja by Sheikh Ibrahim Qodsi Ganjavi (Kocherli, 1925, p. 611) were also commissioned by this government's authorities.

\subsection{References}

Karim Agha Fateh has based his book on verbal history (Fateh, 1384, pp. 135-136). Verbal information included in this work is divided into two parts. The first part of the information is story-like and originates in the oral narration existing in the folkloric literature of the Sheki region. The second and main part of the information has been collected from some informed people who all belonged to the author's family. He has even eye-witnessed some of the events mentioned in the work and has played a role in some of them. 
Of course, he does not always rely on what he hears and adds research in historiographical works to verbal history. He repeatedly owns having used "a historical book titled Alam Ara." It seems that the most available Alam Ara in the historian's lifetime period has been Alam Ara-e Abbasi by Eskandar Bey Monshi. Today, several transcripts of Alam Ara-e Abbasi history book written in 12 and $13^{\text {th }}$ centuries (A.H) are available in Republic of Azerbaijan's Science Academy's Institute of Transcripts (Adelov, 1380, pp. 44-45). Comparing A History of the Sheki Khans with some parts of Alam Ara-e Abbasi shows that Fateh has translated, summarized and explicated some parts and incorporated them into his work. Karim Agha Fateh has used a simple language in this rewriting and has voided panegyrics (Monshi, 1377, p. 135; Fateh, 1384, pp. $136 \& 137$ ).

\subsection{Form of the Work and the Historian's Approach}

The form of this work is chronological. Events are reported in a chronological order and all events are given in the framework of describing political life of local rulers.

Karim Agha Fateh's approach in writing this work is a completely descriptive and narrative one. Like many other historiographical works of the ancient Orient, no signs of analytical and comparative studies are observed in this work.

Nowhere throughout the book the historian does praise anybody and panegyrics are occasional and only in the final section of the book there are some panegyrics for some of the heads of the Tsarian Russian government. For instance, in referring to the name of the Russian Emperor, he only once uses the phrase "King and protector of the world, the Great Emperor" (Fateh, 1384, p. 150).

\subsection{Referencing of the Work}

A Brief History of the Sheki Khans (written in 1829) is one of the forerunners of the local histories of Southern Caucasian Moslem region in the $19^{\text {th }}$ century to the extent that this book is written prior to such well-known books as Abbas Goli Agha Bakikhanov's Gulistan-e Eram (1878), Mirza Jamal Garabaghi's History of Garabagh (1847) and Mirza Adigozel Bey's The Book of Garabagh (1845). Hence, there is the possibility that the mentioned historians might have used A Brief History of the Sheki Khans as a source.

The most important adaptation of the book is made by Hadji Sayyid Abdulhemid in his On Sheki Khans and their Lineage. These two books have many similarities in terms of form and content. Also, the two historians had been contemporaneous. Even both works are written in Azerbaijani Turkish. Nevertheless, Hadji Sayyid Abdulhemid wrote his work after Fateh had deceased. In part of Afandi's work, it is said, "Fath Ali Khan had son named Karim Agha, who has passed away" (Abdulhemid, 1993, p. 22).

In addition, while Fateh reports his book's last historical event happening in 1806 and cites 1828 as the year he finished his book, Hadji Sayyid Abdulhemid writes about the events of the year 1830. Therefore, if we assume that they both had not used a single source, it is possible that Hadji Sayyid Abdulhemid has used Agha Karim Fateh's A Brief History of Sheki Khans. Moreover, there is no doubt that Mustafa Agha Shukhi, Fateh's son, has used his father's work in his own book Stories from Lives of Nuxa Khans written in 1866 (Kocherli, 1926, p. 97).

\section{Conclusion}

A Brief History of Sheki Khans is a work by Karim Agha Fateh. This work is the pioneer local Sheki historiography in the $19^{\text {th }}$ century and one of the first local histories of the Southern Caucasian Moslem region in this period. The error made by some researchers about the authorship of the work stems from their want of attention to the text because Fateh introduces himself repeatedly, though indirectly, throughout the book. The author has been a celebrated poet of his times and despite his mastery of Persian and Arabic, he has written his work in Azerbaijani Turkish. Creating historiographical works in this language in the region and the time span studied here has been a break with traditions. The work's simplicity and lack of any literary figures and embellishments is also the result of the fact the historian writes in a language in which he does not have sufficient literacy and there is no model from which to imitate.

Although in creating this work the historian has used Iranian historiographical sources, Iranian traditions like prologues and epilogues replete with praises and laudations, sophisticated and arcane literary language, employing poems, parables and Hadiths, Persian writing, etc. are not seen in it. Despite all that, like many Iranian historiographers, Karim Agha Fateh is content with mere historiography and has avoided any analytical and comparative study.

In composing this work, Fateh has been encouraged and supported by an anonymous person. His reverential words about this person and his familial connection with the khans whom the Russian government supported and the Russians' policy regarding creating of local histories in this region all strengthen the conjecture that writing 
of A Brief History of the Sheki Khans could have been encouraged by the authorities of the Russian government in the Sheki Province.

\section{References}

Abdulhemid, H. S. (1993). The Sheki Khans and Their Lineage. Baku: Azerbaijan Encyclopedia Publication Association.

Adigozel, B. M. (2006). Garabaghnameh. Garabaghnamehler (Vol. 1). Baku: Sherq-Qerb.

Adilov, M. (1380). List of Persian Manuscripts in the Manuscript Institute of The Republic of Azerbaijan's Science Academy (Vol. 1). Tehran: National Documents Organization of Iran.

Ahmadov, S. (2006). One Hundred Historical Figures of Azerbaijan. Baku: Ayna.

Aliyarli, S. (2007). Historical Sources of Azerbaijan. Baku: Chiraq.

Asef, M. (2537). In M. Moshiri (Ed.), Rustam-ul Tavarikh. Tehran: Amir Kabir.

Babayev, F. (1993). In K. A. Fateh (Ed.), Introduction to A Brief History of the Sheki Khans. Baku: Azerbaijan Encyclopedia Publication Association.

Barazandeh, A. (1388). Asli and Karam. Tabriz: Neda-e Shams.

Farrukhi, G. H. (1389). Asli and Karam. Tabriz: Akhtar.

Fateh, K. A. (1384). History of Sheki Khanate. In H. Ahmadi (Ed.), Three Papers on Caucasia. Tehran: Institute of Iran's Contemporary History.

Fateh, K. A. (1993). A Brief History of the Sheki Khans. Baku: Azerbaijan Encyclopedia Publication Association.

Garabaghi, J. (1384). In H. Ahmadi (Ed.), History of Garabagh. Tehran: Ministry of Foreign Affairs.

Ismayil, M., \& Baghirova, M. (1997). Sheki Khan Neshin. Baku: Azer Nashr.

Javanshir, R. Q. (1384). Panah Khan and Ibrahim Khan's Rules in Garabagh Province. In H. Ahmadi (Ed.), Three Papers on Caucasia. Tehran: Institute of Iran's Contemporary History.

Khezani, M. M. (2006). The Book of Garabagh History. Garabaghname (Vol. 2). Baku: Sherq-Qerb.

Kocherli, F. (1925). Materials from literary history of Azerbaijan (Vol. 1, Section 2). Baku: Azer Nashr.

Kocherli, F. (1926). Materials from literary history of Azerbaijan (Vol. 2, Section 2). Baku: Azer Nashr.

Melikov, R., \& Ibrahimov, N. (2004). A Glossary of Historical Words of schools. Baku: Ayana.

Monshi, E. (1377). In M. E. Rezvani (Ed.), Alam Arae Abbasi History (Vol.1). Tehran: Donya-ye Ketab.

Pashayeva, M. Z., \& Hajiyeva (2005). Salman Mumtaz Archive. Baku: Nurlan.

Peery, J. (2008). The Zand Dynasty. In P. Avery (Ed.), The Cambridge History of Iran. Cambridge: Cambridge University Press.

Qodsi, A. A. (1382). Gulistan-e Eram. Tehran: Ministry of Foreign Affairs.

Republic of Azerbaijan Encyclopedia. (2005). Baku: Lider.

Rumlu, H. (1357). In A. H. Navae (Ed.), Ahsan-ul Tavarikh. Tehran: Babak.

Sami, S. (1314). Qamus-ul A'lam (Vol. 5). Istanbul: Mehran Matba'asi.

Savory, R. (1380). The Safavids. Tehran: Movalli.

Shirvani, Z. (1337). In A. H. Rabbani (Ed.), Riza-ul Syiaha. Tehran: Sa'di.

Shirvani, Z. (1348). Hadaeq-ul Syiaha. Tehran: University Publication Organization.

Soviet Azerbaijan Encyclopedia. (1981). Baku: Socialist Republic of Azerbaijan Publications.

Veledi, E. Z. (2009). Historical Geography of Azerbaijan. Baku: Tehsil.

Zyiad Khan, A. K. (1389). Azerbaijan Republic. Tabriz: Akhtar. 